\title{
MODIFIKASI TEPUNG GANYONG (Canna edulis Kerr.) METODE HEAT MOISTURE TREATMENT PADA SUHU DAN WAKTU PEMANASAN BERBEDA DAN APLIKASI TEPUNG PADA PEMBUATAN COOKIES
}

\author{
Yudi Garnida \\ Hervelly \\ Rima Nuary Rahma

\begin{abstract}
Program Studi Teknologi Pangan, Fakultas Teknik, Universitas Pasundan, Jl. Dr.Setiabudi No 93, Bandung, 40153, Indonesia

E-mail : yudigarnida@unpas.ac.id
\end{abstract}

\begin{abstract}
The purpose of this study was to determine the effect of modification of flour ganyong with temperature variations and heating time can improve the characteristics of flour ganyong and increase its use in food processing. The experimental design used in this study is a 3 x 3 factorial pattern in Randomized Block Design (RBD) and replication conducted three times, resulting in 27 experimental units. Factors used in the study were Heat Moisture Treatment (HMT) heating temperature $\left(80^{\circ} \mathrm{C}, 90^{\circ} \mathrm{C}\right.$ and $100^{\circ} \mathrm{C}$ ) and Heat Moisture Treatment (HMT) heating time (1 hour, 2 hours and 3 hours). The main research responses include chemical responses: pasting properties, moisture content, amylose content and crude fiber content. Based on the result of the research, Heat Moisture Treatment (HMT) heating temperature has an effect on pasting properties, moisture content, amylose content and crude fiber content. Heat Moisture Treatment (HMT) heating time has an effect on pasting properties, moisture content, amylose content and crude fiber content. The interaction between temperature and heating modification time of Heat Moisture Treatment (HMT) has an effect on pasting properties, moisture content, amylose content and crude fiber content. The result of this research is the sample of $\mathrm{m} 3 \mathrm{n} 3$ (heating temperature $100^{\circ} \mathrm{C}$ and heating time 3 hours) with average water content $5,47 \%$, amylose $27,07 \%$ and viscosity setback $856,7 \mathrm{Cp}$. The preparation of cookies from selected modified ganyong flour is carried out by the organoleptic response test. Based on the test results of ganyong flour cookies modification Heat Moisture Treatment (HMT) is preferred in terms of taste, color and texture.
\end{abstract}

Keyword: Flour Ganyong, Heat Moisture Treatment, Cookies

\section{Pendahuluan}

Potensi ketersediaan pangan lokal di Indonesia sangat melimpah, diantaranya adalah umbi-umbian. Pemanfaatan umbi-umbian di Indonesia belum dimanfaatkan secara optimal, salah satunya umbi ganyong. Umbi ganyong sangat baik

digunakan sebagai sumber karbohidrat untuk penyediaan energi. Ganyong merupakan tanaman yang memiliki banyak manfaat. Umbi tua dimanfaatkan sebagai sumber pati, umbi muda dibuat sayur atau dikukus, dan bagian tajuknya untuk pakan ternak (Indastri dkk, 2001).

Sentra produksi ganyong di Jawa Barat terdapat di Kabupaten Ciamis. Menurut (Dinas Pertanian Tanaman Pangan Kabupaten Ciamis, 2009 dalam Septian, 2010), luas lahan ganyong di Kabupaten Ciamis yaitu 204 Ha dengan produktivitas mencapai 2.847 ton pertahunnya. Umbi ganyong segar memiliki nilai ekonomi yang rendah, sehingga perlu suatu upaya untuk meningkatkan nilai tambah (added value) dari umbi ganyong tersebut, salah satu cara yaitu diolah menjadi beranekaragam produk. Alternatif pengolahan umbi ganyong agar dapat meningkatkan nilai jual yaitu mengolah umbi ganyong menjadi tepung. Tepung ganyong memiliki karakteristik yang cukup baik untuk dikembangkan dalam industri bakery (Hidayat, 2013). Tepung ganyong dalam bentuk alaminya memiliki sifat - sifat yang membatasi dalam penggunaannya. Menurut Jyothi, et al., (2009) sifat - sifat tersebut antara lain viskositas yang tinggi, water absorptionn index dan kelarutan tepung yang rendah. Sifat ini dipengaruhi oleh kandungan pati yang terdapat pada tepung ganyong. Menurut Kusnandar (2010) untuk mengatasi masalah sifat pati alami yang sulit diaplikasikan dalam pengolahan pangan, maka pati alami sering dimodifikasi agar menghasilkan pati yang memiliki sifat-sifat reologi berbeda dari pati alami sehingga dapat memperluas penggunaannya dalam pengolahan pangan serta menghasilkan karakteristik produk yang diinginkan. Metode modifikasi dapat dilakukan secara fisik, kimia dan

enzimatis. Ketiga modifikasi ini, yang paling efisien untuk diterapkan adalah modifikasi secara fisik dengan menggunakan panas lembab atau Heat Moisture Treatment (HMT). Proses modifikasi pati dengan metode Heat Moisture Treatment (HMT) menggunakan batasan kadar air yang rendah, yaitu lebih kecil 35\% dengan suhu pemanasan yang lebih tinggi nilainya dari suhu gelatinisasi pati (Collado et al., 2001). 
Karakteristik fisiko-kimia dan fungsional pati yang dimodifikasi dengan metode Heat Moisture Treatment (HMT) sangat beragam dan dipengaruhi oleh beberapa faktor seperti jenis (sumber) pati, kadar amilosa dan tipe kristalisasi pati. Karakteristik pati modifikasi metode Heat Moisture Treatment (HMT) juga dipengaruhi oleh kondisi proses seperti suhu, kadar air, $\mathrm{pH}$ dan lama waktu pemanasan (Syamsir, 2012).

\section{Metode Penelitian}

Bahan-bahan yang digunakan pada penelitian adalah umbi ganyong yang diperoleh dari Pasar Baru Bandung varietas ganyong putih sebanyak $20 \mathrm{~kg}$, aquades, gula halus merk Pohon Kenari, susu skim merk Sunlac, margarin merk Blue band, kuning telur, garam dan baking powder merk "KoepoeKoepoe".

Bahan-bahan kimia yang digunakan pada penelitian adalah etanol 95\%, NaOH $1 \mathrm{~N}, \mathrm{NaHSO} 3500$ ppm, asam asetat $0,5 \mathrm{~N}$, iodin, $\mathrm{H} 2 \mathrm{SO} 41,25 \% \mathrm{~N}, \mathrm{NaOH}$ $3,25 \%$.

Alkohol 36\%, kertas saring, dan aquades. Alatalat yang digunakan dalam penelitian ini adalah tray, tunnel dryer, ayakan 100 mesh, necara digital merk ohaus, botol semprot, refrigator, oven merk Trisonic, blender merk Philips dan mixer Philips. Alat-alat yang digunakan untuk analisis adalah tang krus, desikator, oven, neraca analitik, penjepit, spatula, pipet volume, neraca digital merk Ohaus, tabung reaksi merk Pyrex, labu takar $100 \mathrm{ml}$, waterbath, spektrofotometer, tabung sentrifuse, sentrifugator, alat viscometer DV-II Pro, labu erlenmeyer, kaki tiga, bunsen, kawat kasa, corong, batang pengaduk, cawan dan oven.

Penelitian terdiri dari penelitian pendahuluan, utama serta lanjutan. Rancangan percobaan yang digunakan pada penelitian ini adalah Rancangan Acak Kelompok (RAK) dengan pola faktorial 3x3 dengan 3 kali pengulangan sehingga diperoleh 27 perlakuan. Rancangan perlakuan terdiri dari dua faktor. Faktor yang pertama yaitu suhu pemanasan modifikasi metode Heat Moisture Treatment (HMT) (M), yang terdiri dari 3 taraf, yaitu : $\mathrm{m} 1=80^{\circ} \mathrm{C}, \mathrm{m} 2=90^{\circ} \mathrm{C}$ dan $\mathrm{m} 3=100^{\circ} \mathrm{C}$. Faktor kedua yaitu waktu pemanasan modifikasi metode Heat Moisture Treatment (HMT) (N) yang terdiri dari 3 taraf, yaitu: $\mathrm{n} 1=1$ jam, $\mathrm{n} 2=2$ jam, $\mathrm{n} 3=3$ jam. Rancangan Respon yang akan dilakukan pada penelitian ini yaitu respon kimia meliputi analisis kadar air menurut (AOAC, 2005), kadar serat kasar (Sudarmadji, 2003), kadar amilosa (SNI 6128-2008), dan sifat amilografi (Brookfield Engineering).

Penelitian pendahuluan yang dikerjakan yaitu pembuatan tepung ganyong. Umbi ganyong putih diolah menjadi tepung untuk dilakukan proses modifikasi pada penelitian utama. Analisa tepung ganyong yaitu kadar air menurut (AOAC, 2005), kadar serat kasar (Sudarmadji, 2003), kadar amilosa (SNI 6128-2008), dan sifat amilografi (Brookfield Engineering).

Penelitian utama yang dikerjakan yaitu modifikasi tepung ganyong dengan variasi suhu dan waktu pemanasan metode Heat Moisture Treatment (HMT) agar dapat dihasilkan tepung modifikasi terpilih yang diaplikasikan dalam pembuatan cookies.

Prosedur penelitian modifikasi tepung ganyong metode Heat Mositure Treatment (HMT), yaitu:

a. Penimbangan

Tepung ganyong yang telah dianalisis kadar airnya, kemudian dilakukan penimbangan menggunakan timbangan digital sebanyak 100 gram.

b. Pengaturan Kadar Air

Tepung yang akan dimodifikasi diatur kadar airnya terlebih dahulu hingga mencapai $25 \%$. Pemilihan kadar air berdasarkan penelitian terdahulu yang dilakukan oleh Pinasthi (2011) tentang modifikasi pati tapioka dan maizena dengan kadar air 25\% mampu memberikan pati termodifikasi Heat Moisture Treatment (HMT) dengan suhu gelatinisasi yang lebih tinggi dan stabilitas termal yang lebih baik terhadap pengaruh pemanasan dan pengadukan. Jumlah aquades ditentukan berdasarkan kesetimbangan massa dan formulasi kesetimbangan massa (Pinasthi 2011).

c. Pendinginan

Tepung yang lembab sebelumnya dimasukan ke dalam loyang yang ditutup dengan alumunium foil. Loyang berisi tepung didiamkan dalam refrigerator dengan suhu $5^{\circ} \mathrm{C}$ selama 12 jam. Proses ini bertujuan untuk penyeragaman kadar air pada tepung (Herawati, 2009).

d. Pemanasan

Tepung yang telah dilakukan penyimpanan selama 12 jam selanjutnya dipanaskan dalam oven dengan suhu pemanasan yaitu $80^{\circ} \mathrm{C}, 90^{\circ} \mathrm{C}, 100^{\circ} \mathrm{C}$ dan waktu pemanasan yaitu 1 jam, 2 jam, dan 3 jam.

e. Pengeringan

Tepung termodifikasi disimpan pada Loyang kemudian dikeringkan menggunakan tunnel dryer selama 5 jam pada suhu $50^{\circ} \mathrm{C}$ (Pangesti dkk., 2014). Proses ini bertujuan untuk mengurangi kadar air pada tepung modifikasi.

\section{f. Penggilingan}

Tepung yang menggumpal pada saat modifikasi akan dilakukan panghalusan kembali dengan menggunakan blender, agar tidak terdapat gumpalangumpalan pada tepung ganyong modifikasi yang dihasilkan.

g. Pengayakan

Setelah dilakukan proses penggilingan, tepung modifikasi akan dilakukan pengayakan menggunakan vibratory screen dengan ukuran 100 mesh (Herawati, 2009). Proses ini bertujuan untuk menyeragamkan ukuran dari tepung ganyong modifikasi. Tepung kasar yang tidak lolos dalam ayakan akan dilakukan penggilingan ulang untuk menghaluskan kembali tepung. h. Analisis Tepung ganyong yang telah dimodifikasi selanjutnya dilakukan analisis kimia, meliputi kadar air, kadar serat kasar, kadar amilosa dan sifat amilografi untuk mengetahui perlakuan Heat Moisture Treatment (HMT) terpilih yang mampu 
mengubah karakteristik fisikokimia. Tepung Heat Moisture Treatment (HMT) dengan kondisi terpilih akan diaplikasikan dalam pembuatan cookies. 3. Penelitian Utama Lanjutan Penelitian utama lanjutan bertujuan untuk mengetahui karakteristik cookies yang terbuat dari tepung ganyong modifikasi metode Heat Moisture Treatment (HMT) yang terpilih. Kriteria penilaian yang digunakan pada penelitian ini yaitu pengujian secara organoleptik dengan uji hedonik (Soekarto, 1985) menggunakan 30 panelis belum terlatih, dimana kriteria penilaian berdasarkan tingkat kesukaan panelis terhadap karakteristik dari tekstur, warna dan rasa cookies tepung ganyong termodifikasi

\section{Hasil dan Pembahasan}

\section{Hasil Penelitian Pendahuluan}

Penelitian pendahuluan yang dilakukan adalah pembuatan tepung dari umbi ganyong putih dan selanjutnya tepung dilakukan analisis kimia yaitu, sifat amilografi, kadar amilosa, kadar serat kasar dan kadar air. Penelitian pendahuluan bertujuan untuk mengetahui adanya perubahan tepung alami dengan tepung yang telah dilakukan proses modifikasi Heat Moisture Treatment (HMT). Hasil analisis kimia tepung ganyong alami dapat dilihat pada Tabel 1.

Tabel 1. Hasil Analisis Kimia Tepung Ganyong Alami

\begin{tabular}{|l|c|c|}
\multicolumn{1}{|c|}{ Respon Kimia } & Satuan & Hasil \\
\hline Kadar Air & $\%$ & 10 \\
\hline Amilosa & $\%$ & 27,87 \\
\hline Serat Kasar & $\%$ & 4,35 \\
\hline Viskositas Setback & $\mathrm{Cp}$ & 2640 \\
\hline $\begin{array}{l}\text { Suhu Awal } \\
\text { Gelatinisasi }\end{array}$ & ${ }^{\circ} \mathrm{C}$ & 74,3 \\
\hline
\end{tabular}

Hasil analisis kimia pada tepung ganyong alami memiliki nilai yang lebih rendah jika dibandingkan dengan penelitian yang dilakukan oleh (Purwaningsih, 2013) yaitu kadar air sebesar 10,09\%, kadar serat kasar $5,12 \%$ dan kadar amilosa sebesar 32,99\%. Hal ini dapat dipengaruhi oleh umur panen umbi ganyong. Menurut Wahid dkk. (1992) dalam Purwaningsih (2013) kadar serat kasar dan kadar pati pada tepung dipengaruhi oleh umur panen umbi, semakin tua umur umbi maka kadar pati dalam umbi akan semakin menurun dan akan terjadi perubahan dari pati menjadi serat Selain itu, menurut Koswara (2009) komponen yang terdapat pada umbi ganyong dipengaruhi oleh iklim, kesuburan tanah dan varietas tanaman.

\section{Hasil Penelitian Utama}

Penelitian utama yang dilakukan untuk mengetahui pengaruh penambahan variasi konsentrasi gelatin cair dari tulang ikan tuna $(8 \%, 10 \%, 12 \%)$ dan perbandingan antara sukrosa dan sirup jagung (1:2, 1:1, 2:1) terhadap karakteristik marshmallow. Marshmallow yang dihasilkan selanjutnya dilakukan uji organoleptik dan uji kimia.

\section{Kadar Air}

Berdasarkan hasil perhitungan ANAVA menunjukkan bahwa suhu, waktu pemanasan modifikasi metode Heat Moisture Treatment (HMT) serta interaksi keduanya berpengaruh terhadap kadar air tepung modifikasi yang dihasilkan. Hal ini diduga selama proses modifikasi Heat Moisture Treatment (HMT) terjadi penguapan air akibat pemanasan. Selain itu, proses pengeringan pasca modifikasi dapat menurunkan kadar air pada tepung modifikasi. Pengaruh interaksi suhu dan waktu pemanasan modifikasi metode Heat Moisture Treatment (HMT) terhadap kadar air tepung modifikasi dapat dilihat pada Tabel 2.

Tabel 2. Pengaruh Interaksi Suhu dan Waktu Pemanasan Modifikasi Metode Heat Moisture Treatment (HMT) Terhadap Kadar Air Tepung Modifikasi (\%).

\begin{tabular}{|c|c|c|c|}
\hline \multirow{2}{*}{$\begin{array}{c}\text { Suhu } \\
\text { Pemanasan } \\
\text { Modifikasi } \\
\text { Metode } \\
\text { HMT (M) }\end{array}$} & \multicolumn{3}{|c|}{$\begin{array}{c}\text { Waktu Pemanasan } \\
\text { Modifikasi Metode HMT } \\
(\mathbf{N}) \\
\end{array}$} \\
\hline & nl & $\mathrm{n} 2$ & n3 \\
\hline $\mathrm{ml}\left(80^{\circ} \mathrm{C}\right)$ & $b^{9,45^{C}}$ & $a^{8,97}$ & $a^{8,96}$ \\
\hline $\mathrm{m} 2\left(90^{\circ} \mathrm{C}\right)$ & ${ }_{b}^{8,50}$ & ${ }_{b} 8,47^{B}$ & $a^{7,99}$ \\
\hline $\mathrm{m} 3\left(100^{\circ} \mathrm{C}\right)$ & $c^{7,65^{\mathrm{A}}}$ & $b^{6,99}{ }^{A}$ & $a^{a^{2}}{ }^{\mathrm{A}}$ \\
\hline
\end{tabular}

Keterangan: Huruf kecil dibaca arah horizontal dan huruf besar dibaca vertikal, huruf yang berbeda menyatakan perbedaan yang nyata pada taraf 5\% pada uji lanjut Duncan.

Pada Tabel 2 menunjukkan pada perlakuan suhu pemanasan $80^{\circ} \mathrm{C}$ berbeda nyata terhadap perlakuan lama waktu pemanasan 1 jam, namun pada perlakuan lama waktu pemanasan 1 jam dan 2 jam tidak berbeda nyata. Perlakuan suhu pemanasan $90^{\circ} \mathrm{C}$ berbeda nyata terhadap lama waktu $3 \mathrm{jam}$, namun pada perlakuan lama waktu pemanasan 1 jam dan 2 jam tidak berbeda nyata. Perlakuan $100^{\circ} \mathrm{C}$ berbeda nyata terhadap perlakuan lama waktu pemanasan 1 jam, 2 jam dan 3 jam. Perlakuan lama waktu pemanasan 1 jam, 2 jam dan 3 jam memiliki perbedaan nyata yang signifikan terhadap perlakuan suhu pemanasan $80^{\circ} \mathrm{C}, 90^{\circ} \mathrm{C}$ dan $100^{\circ} \mathrm{C}$.

Hasil penelitian menunjukkan adanya perbedaan yang nyata pada setiap perlakuan dapat disebabkan pada proses modifikasi dapat terjadi penguapan air pada bahan karena adanya proses pemanasan. Suhu pemanasan yang semakin tinggi dapat menyebabkan air bebas, air yang terikat dan air yang tidak terikat dalam bahan dapat menguap secara berlebih sehingga terjadi penurunan kadar air pada tepung ganyong modifikasi.

Menurut Sumarlin (2011) perlakuan suhu Heat Moisture Treatment (HMT) cenderung mengakibatkan kadar air pati menjadi lebih rendah bila dibandingkan dengan pati alaminya. Hal ini karena suhu yang tinggi menyebabkan air yang terikat pada pati menguap, sehingga kadar air menjadi rendah. 
Waktu pemanasan pada saat proses modifikasi yang semakin lama dapat menyebabkan terjadinya pengembangan granula pati sehingga memiliki rongga yang lebih besar dan pada proses pengeringan air akan lebih mudah untuk menguap. Hal ini didukung oleh Haryadi (1999) dalam Puung (2012) pada saat modifikasi Heat Moisture Treatment (HMT) granula pati yang telah membengkak cenderung memiliki rongga yang lebih besar sehingga akan mengakibatkan air menjadi lebih mudah menguap pada saat pengeringan.

\section{Sifat Amilografi}

\section{a. Suhu Awal Gelatinisasi (SAG)}

Suhu awal gelatinisasi (SAG) adalah suhu saat granula pati mulai menyerap air dan mengalami peningkatan viskositas. Berdasarkan hasil perhitungan ANAVA menunjukkan suhu, waktu pemanasan modifikasi metode Heat Moisture Treatment (HMT) serta interaksi keduanya berpengaruh terhadap suhu awal gelatinisasi tepung modifikasi. Hal ini diduga pada suhu pemanasan dan lama waktu pemanasan menyebabkan terputusnya sebagian ikatan hidrogen inter- dan intra molekul amilosa dan amilopektin dalam granula pati yang mengakibatkan berubahnya struktur granula pati. Pengaruh interaksi suhu dan waktu pemanasan modifikasi metode Heat Moisture Treatment (HMT) terhadap suhu awal gelatinisasi tepung modifikasi dapat dilihat pada Tabel 3.

Tabel 3. Pengaruh Interaksi Suhu dan Waktu Pemanasan Modifikasi Metode Heat Moisture Treatment (HMT) Terhadap Suhu Awal Gelatinisasi Tepung Modifikasi $\left({ }^{\circ} \mathrm{C}\right)$

\begin{tabular}{|c|c|c|c|}
\hline \multirow{2}{*}{$\begin{array}{l}\text { Suhu } \\
\text { Pemanasan } \\
\text { Modifilcasi } \\
\text { Metode } \\
\text { HMT (A) }\end{array}$} & \multicolumn{3}{|c|}{$\begin{array}{l}\text { Walktu Pemanasan } \\
\text { Modifilcasi Metode HMr } \\
\text { (N) }\end{array}$} \\
\hline & $\begin{array}{c}\text { nl } \\
(1 \text { jam })\end{array}$ & $\begin{array}{c}\frac{\mathrm{w} 2}{(2 \mathrm{jam})} \\
\text { (1) }\end{array}$ & $\begin{array}{c}\mathrm{n}^{3} \\
(3 \mathrm{jam})\end{array}$ \\
\hline $\mathrm{ml}\left(80^{\circ} \mathrm{C}\right)$ & $a^{74,3^{A}}$ & $\begin{array}{l}\mathrm{b}^{85,3} \\
\end{array}$ & $c^{90,0^{B}}$ \\
\hline $\mathrm{m} 2\left(90^{\circ} \mathrm{C}\right)$ & $a^{A 4,2}$ & ${ }^{7}{ }^{\text {B }}$ & $b^{79,1}$ \\
\hline $\mathrm{m}^{3}\left(100^{\circ} \mathrm{C}\right)$ & $b^{84,7}$ & $a^{76,2^{\mathrm{A}}}$ & $c^{94,4^{C}}$ \\
\hline
\end{tabular}

Keterangan: Huruf kecil dibaca arah horizontal dan huruf besar dibaca vertikal, huruf yang berbeda menyatakan perbedaan yang nyata pada taraf 5\% pada uji lanjut Duncan.

Pada Tabel 3 menunjukkan pada perlakuan suhu pemanasan $80^{\circ} \mathrm{C}$ berbeda nyata terhadap perlakuan lama waktu pemanasan 1 jam, 2 jam dan 3 jam. Perlakuan suhu pemanasan $90^{\circ} \mathrm{C}$ berbeda nyata terhadap lama waktu 1 jam, namun pada perlakuan lama waktu pemanasan 2 jam dan 3 jam tidak berbeda nyata. Perlakuan $100^{\circ} \mathrm{C}$ berbeda nyata terhadap perlakuan lama waktu pemanasan 1 jam , 2 jam dan 3 jam. Perlakuan lama waktu pemanasan 1 jam, berbeda nyata terhadap perlakuan suhu pemanasan $100^{\circ} \mathrm{C}$, namun tidak berbeda nyata pada perlakuan suhu pemanasan $80^{\circ} \mathrm{C}$ dan $90^{\circ} \mathrm{C}$. Perlakuan waktu pemanasan 2 jam dan 3 jam memiliki perbedaan nyata yang signifikan terhadap perlakuan suhu pemanasan $90^{\circ} \mathrm{C}$ dan $100^{\circ} \mathrm{C}$. Perbedaan suhu awal gelatinisasi dapat disebabkan karena adanya pembentukan ikatan antara amilosa dan amilopektin yang dihasilkan pada saat proses modifikasi sehingga membutuhkan suhu yang lebih tinggi agar granula pati dapat menyerap air dan terjadinya peningkatan viskositas.

Menurut Takahashi et al., (2005) selama proses Heat Moisture Treatment (HMT) memungkinkan terbentuknya ikatan baru yang lebih kompleks antara amilosa pada bagian kristalin dengan amilopektin pada bagian amorpous, sehingga menghasilkan formasi kristalin baru yang memiliki ikatan lebih kuat dan rapat. Terbentuknya formasi kristalin tersebut yang menyebabkan pati membutuhkan suhu yang lebih tinggi untuk menyerap air.

Perlakuan dengan lama waktu modifikasi yang berbeda memberikan hasil suhu awal gelatinisasi yang bervariasi. Menurut Stute (1992) dalam Ahmad (2009) pati hasil modifikasi Heat Moisture Treatment (HMT) memiliki dua peak gelatinisasi dan kisaran suhu gelatinisasi yang cukup beragam. Adanya perbedaan entalpi dan suhu gelatinisasi pada pati Heat Moisture Treatment (HMT) menunjukkan bahwa proses Heat Moisture Treatment (HMT) menghasilkan pembentukan struktur kristalin baru yang memiliki perbedaan stabilitas panas. Perbedaan kestabilan panas pada pati hasil modifikasi Heat Moisture Treatment (HMT) dapat menyebabkan terjadinya gelatinisasi pada sebagian pati yang kurang tahan terhadap panas.

\section{b. Viskositas Puncak}

Viskositas maksimum atau viskositas puncak menunjukkan kondisi pengembangan maksimum granula pati yang selanjutnya akan pecah dan menurunkan viskositas. Tepung ganyong alami dan tepung ganyong hasil modifikasi pada setiap perlakuan tidak diketahui nilai suhu puncak gelatinisasi maupun nilai viskositas puncaknya.

Menurut Scoch dan Maywald (1968) dalam Utami (2010) pati yang telah mencapai suhu awal gelatinisasi akan menyerap air dan mengalami peningkatan viskositas. Penyerapan air secara terus menerus akan meningkatkan viskositas pasta pati sampai akhirnya granula pati akan pecah kemudian mengalami penurunan viskositas. Namun pada peneitian ini, hal tersebut tidak ditemukan pada tepung ganyong alami maupun tepung hasil modifikasinya. Tepung alami dan tepung Heat Moisture Treatment (HMT) terus mengalami peningkatan viskositas selama proses pemanasan dan pendinginan sehingga tidak ada viskositas puncak sehingga kedua pati tersebut dapat dikategorikan sebagai pati tipe $\mathrm{C}$.

Menurut Chen (2003) dalam Syamsir (2012) pola viskositas pati dikelompokkan menjadi empat tipe yaitu, tipe A dengan puncak pasta tinggi dengan pengenceran cepat selama pemanasan, tipe B dengan puncak pasta 
lebih rendah dan pengenceran yang tidak terlalu rendah selama pemanasan, tipe $\mathrm{C}$ tidak menunjukkan adanya puncak tetapi lebih pada pembentukan viskositas yang sangat tinggi dan tetap konstan atau meningkat selama pemanasan dan tipe D konsentrasinya perlu dinaikkan dua kali sampai tiga kali lipat untuk menghasilkan viskositas pasta panas seperti tipe $\mathrm{C}$.

\section{c. Viskositas Setback}

Viskositas setback adalah ukuran yang digunakan untuk menentukan kecenderungan retrogradasi. Menurut Winarno (2002) retrogradasi merupakan proses terbentuknya jaringan mikrokristal dari molekul amilosa yang berikatan kembali satu sama lain atau dengan percabangan amilopektin di luar granula setelah pasta didinginkan. Berdasarkan hasil perhitungan ANAVA menunjukkan suhu, waktu pemanasan modifikasi metode Heat Moisture Treatment (HMT) serta interaksi keduanya berpengaruh terhadap viskositas setback tepung modifikasi yang dihasilkan. Pengaruh interaksi suhu dan waktu pemanasan modifikasi metode Heat Moisture Treatment (HMT) terhadap viskositas setback tepung modifikasi dapat dilihat pada Tabel 4 .

Tabel 4. Pengaruh Interaksi Suhu dan Waktu Pemanasan Modifikasi Metode Heat Moisture Treatment (HMT) Terhadap Viskositas Setback Tepung Modifikasi (Cp)

\begin{tabular}{|c|c|c|c|}
\hline \multirow{2}{*}{$\begin{array}{c}\text { Suhu } \\
\text { Pemanasan } \\
\text { Modifilcasi } \\
\text { Metode } \\
\text { HMT (MD }\end{array}$} & \multicolumn{3}{|c|}{$\begin{array}{c}\text { Walku Pemanasan } \\
\text { Modifilasi Metode HurT (N) }\end{array}$} \\
\hline & $\left(1_{\mathrm{jam}}^{\mathrm{nl}}\right)$ & $(2 \mathrm{jam})$ & $(3 \mathrm{jam})$ \\
\hline $\mathrm{ml}\left(\$ 0^{\circ} \mathrm{C}\right)$ & $\begin{array}{r}{ }_{1}^{A} \\
1773,3 \\
a^{3}\end{array}$ & ${ }^{2283,3}{ }^{A}$ & $\begin{array}{l}{ }_{2793,3}{ }^{\mathrm{C}} \\
\mathrm{C}^{-}\end{array}$ \\
\hline $\mathrm{m} 2\left(90^{\circ} \mathrm{C}\right)$ & $\begin{array}{r}\text { B } \\
3866,7 \\
b \\
\end{array}$ & $\begin{array}{l}C^{C} \\
4225,0 \\
c^{2}\end{array}$ & 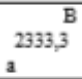 \\
\hline $\mathrm{m} 3\left(100^{\circ} \mathrm{C}\right)$ & $\begin{array}{r}\text { C } \\
4181,7 \\
c^{2}\end{array}$ & ${ }^{2791,7}{ }^{\text {B }}$ & $c^{856,7^{A}}$ \\
\hline
\end{tabular}

Keterangan: Huruf kecil dibaca arah horizontal dan huruf besar dibaca vertikal, huruf yang berbeda menyatakan perbedaan yang nyata pada taraf 5\% pada uji lanjut Duncan.

Pada Tabel 4 menunjukkan perlakuan suhu pemanasan $80^{\circ} \mathrm{C}, 90^{\circ} \mathrm{C}$ dan $100^{\circ} \mathrm{C}$ berbeda nyata terhadap perlakuan lama waktu pemanasan 1 jam, 2 jam dan 3 jam. Perlakuan lama waktu pemanasan 1 jam, 2 jam dan 3 jam berbeda nyata terhadap perlakuan suhu pemanasan $90^{\circ} \mathrm{C}$ dan $100^{\circ} \mathrm{C}$. Perbedaan ini dapat disebabkan karenakan proses pemanasan dapat menyebabkan terjadinya penyusunan ulang struktur granula pati pada tepung sehingga viskositas setback yang dihasilkan bervariasi.

Hasil penelitian menunjukkan bahwa perlakuan Heat Moisture Treatment (HMT) memberikan respon viskositas setback yang beragam yang merupakan kombinasi pengaruh perlakuan waktu dan suhu modifikasi yang diterapkan. Zavareze dan Dias (2010) menambahkan bahwa viskositas setback dipengaruhi oleh jumlah amilosa yang terlepas, ukuran granula, rigiditas, dan granula mengembang yang tidak terfragmentasi. Hasil viskositas setback terendah yaitu pada perlakuan $\mathrm{m} 3 \mathrm{n} 3$ dengan nilai rata-rata sebesar 856,7 Cp. Semakin tinggi suhu pemanasan dan semakin lama waktu pemanasan modifikasi metode Heat Moisture Treatment (HMT) dapat menurunkan viskositas setback pada tepung ganyong modifikasi Heat Moisture Treatment (HMT). Penyebab penurunan viskositas setback ini diduga karena pembentukan kompleks antara amilosa, amilosa dengan amilopektin serta amilosa dengan lemak yang terjadi selama proses Heat Moisture Treatment (HMT) berlangsung, sehingga mengurangi kemampuan pati terutama amilosa untuk saling berikatan kembali (retrogradasi). Hal tersebut didukung oleh Zavareze dan Dias (2010) penurunan viskositas balik diakibatkan oleh penyusunan ulang antar molekul amilosa dan amilopektin yang menyebabkan ikatan antar molekul amilosa dan amilopektin di dalam pati menjadi lebih banyak sehingga pada akhirnya menurunkan kecenderungan untuk mengalami retrogradasi.

Kadar Amilosa Berdasarkan hasil perhitungan ANAVA menunjukkan suhu, waktu pemanasan modifikasi metode Heat Moisture Treatment (HMT) serta interaksi keduanya berpengaruh terhadap kadar amilosa tepung modifikasi yang dihasilkan. Hal ini diduga bahwa suhu pemanasan dan lama waktu pemanasan dapat mengakibatkan sktruktur amilosa dan amilopektin yang terdapat pada tepung membentuk ikatan baru. Pengaruh interaksi suhu dan waktu pemanasan modifikasi metode Heat Moisture Treatment (HMT) terhadap kadar amilosa tepung modifikasi dapat dilihat pada Tabel 5 .

Tabel 5. Pengaruh Interaksi Suhu dan Waktu Pemanasan Modifikasi Metode Heat Moisture Treatment (HMT) Terhadap Kadar Amilosa Tepung Modifikasi (\%)

\begin{tabular}{|c|c|c|c|}
\hline \multirow{2}{*}{$\begin{array}{c}\text { Suhu } \\
\text { Pemanasan } \\
\text { Modifileasi } \\
\text { Metode } \\
\text { HMrT (MD }\end{array}$} & \multicolumn{3}{|c|}{$\begin{array}{l}\text { Walktu Pemanasan } \\
\text { Modifilasi Metode HMrT }\end{array}$} \\
\hline & $\underset{(1) \text { jam })}{\mathrm{nl}}$ & 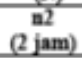 & $\begin{array}{c}\mathrm{n}^{\mathbf{3}} \\
(3 \mathrm{jam})\end{array}$ \\
\hline $\mathrm{ml}\left(90^{\circ} \mathrm{C}\right)$ & ${ }^{27,86}$ & $b^{27,83}$ & $27,42^{\mathrm{B}}$ \\
\hline $\mathrm{m} 2\left(90^{\circ} \mathrm{C}\right)$ & $b^{27,09}$ & $a^{26,73}$ & $c^{27,78^{C}}$ \\
\hline $\mathrm{m}^{3}\left(100^{\circ} \mathrm{C}\right)$ & $a^{26,54}$ & $27,22^{\mathrm{B}}$ & $b^{27,07^{A}}$ \\
\hline
\end{tabular}

Keterangan: Huruf kecil dibaca arah horizontal dan huruf besar dibaca vertikal, huruf yang berbeda menyatakan perbedaan yang nyata pada taraf 5\% pada uji lanjut Duncan.

Pada Tabel 5 menunjukkan perlakuan suhu pemanasan $80^{\circ} \mathrm{C}$ berbeda nyata terhadap perlakuan lama waktu pemanasan $3 \mathrm{jam}$, namun tidak berbeda nyata terhadap perlakuan lama waktu pemanasan 1 jam dan 2 jam. Perlakuan suhu pemanasan $90^{\circ} \mathrm{C}$ dan $100^{\circ} \mathrm{C}$ berbeda nyata terhadap lama waktu pemanasan $1 \mathrm{jam}, 2$ jam dan 3 jam. Perlakuan lama waktu pemanasan 1 jam, 2 jam dan 3 jam berbeda nyata terhadap perlakuan suhu pemanasan $80^{\circ} \mathrm{C}, 90^{\circ} \mathrm{C}$ dan $100^{\circ} \mathrm{C}$. Perbedaan kadar amilosa dapat terjadi karena pada proses pemanasan yang tinggi dapat terjadinya pengeluaran amilosa dari 
granula pati sehingga amilosa pada tepung modifikasi menjadi lebih rendah bila dibandingkan dengan kadar amilosa tepung tanpa modifikasi.

Hasil penelitian menunjukkan bahwa perubahan kadar amilosa yang terjadi antar perlakuan suhu dan lama modifikasi Heat Moisture Treatment (HMT) cenderung tidak stabil dan membentuk pola yang fluktuatif, namun demikian kadar amilosa tepung termodifikasi Heat Moisture Treatment (HMT) lebih rendah dibandingkan dengan kadar amilosa tepung alami. Kadar amilosa pada tepung Heat Moisture Treatment (HMT) memiliki pola kecenderungan menurun. Menurunnya kadar amilosa setelah Heat Moisture Treatment (HMT) disebabkan terjadinya pengikatan amilosa-amilosa ataupun amilosaamilopektin. Amilosa yang diikat dengan iodin adalah amilosa bebas, makin banyak amilosa bebas yang diikat iodin, makin sedikit amilosa yang bisa berikatan dengan amilosa atau amilopektin (Varatharajan et al., 2011).

Kadar amilosa yang rendah diduga makin banyaknya amilosa yang telah berikatan dengan amilosa lainnya atau amilopektin. Menurut Siwi (2012) pengukuran kadar amilosa menggunakan pengikatan iodin. Iodin akan terikat pada struktur helix amilosa yang kemudian akan membentuk warna biru. Namun, pada modifikasi Heat Moisture Treatment (HMT), panas yang digunakan akan merenggangkan spiral struktur helix sehingga kemampuan menangkap iodin akan berkurang. Semakin tinggi suhu yang digunakan maka akan semakin banyak helix yang terurai.

\section{Kadar Serat}

Kasar Berdasarkan hasil perhitungan ANAVA menunjukkan suhu, waktu pemanasan modifikasi metode Heat Moisture Treatment (HMT) serta interaksi keduanya berpengaruh terhadap kadar serat kasar tepung modifikasi yang dihasilkan. Pengaruh interaksi suhu dan waktu pemanasan modifikasi metode Heat Moisture Treatment (HMT) terhadap kadar serat kasar tepung modifikasi dapat dilihat pada Tabel 6 .

Tabel 6. Pengaruh Interaksi Suhu Dan Waktu Pemanasan Modifikasi Metode Heat Moisture Treatment (HMT) Terhadap Kadar Serat Kasar Tepung Modifikasi (\%).

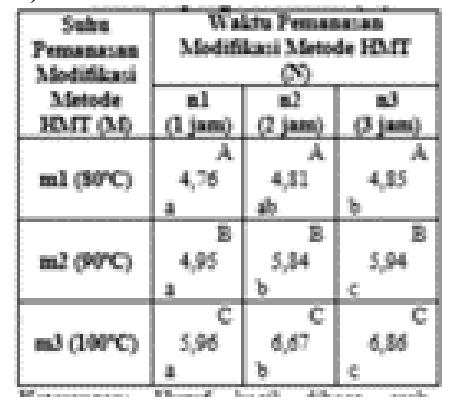

Keterangan: Huruf kecil dibaca arah horizontal dan huruf besar dibaca vertikal, huruf yang berbeda menyatakan perbedaan yang nyata pada taraf 5\% pada uji lanjut Duncan.

Pada Tabel 6 menunjukkan pada perlakuan suhu pemanasan $80^{\circ} \mathrm{C}$ tidak berbeda nyata terhadap perlakuan lama waktu pemanasan 1 jam, 2 jam dan 3 jam. Perlakuan suhu pemanasan $90^{\circ} \mathrm{C}$ dan $100^{\circ} \mathrm{C}$ menunjukkan perbedaaan nyata yang signifikan terhadap lama waktu pemanasan 1 jam, 2 jam dan 3 jam. Perlakuan lama waktu pemanasan 1 jam, 2 jam dan 3 jam berbeda nyata secara signifikan terhadap perlakuan suhu pemanasan $80^{\circ} \mathrm{C}, 90^{\circ} \mathrm{C}$ dan $100^{\circ} \mathrm{C}$. Hal ini disebabkan pada suhu pemanasan yang tinggi dan waktu pemanasan yang lama akan menyebabkan penurunan kadar air. Penurunan kadar air ini akan meningkatkan komponen seperti karbohidrat, lemak dan protein. Dimana serat kasar merupakan bagian dari kelompok karbohidrat. Hal ini didukung oleh Muchtadi dan Ayustaningwarno (2010) dengan mengurangi kadar airnya, bahan pangan akan mengandung senyawa seperti karbohidrat, protein dan mineral yang lebih tinggi.

\section{Penelitian Utama Lanjutan}

Berdasarkan hasil uji kadar air, sifat amilografi dan kadar amilosa. Perlakuan terbaik dipilih mengacu pada karakteristik tepung ganyong modifikasi yang memiliki nilai ratarata dengan hasil analisis terendah yaitu pada perlakuan $\mathrm{m} 3 \mathrm{n} 3$ (suhu pemanasan $100^{\circ} \mathrm{C}$ dan waktu pemanasan 3 jam) dengan rata-rata nilai kadar air sebesar 5,47\%, kadar amilosa $27,07 \%$ dan viskositas setback 856,7 Cp.

Hasil analisis kadar air terendah dipilih karena kadar air menentukan daya awet dari suatu produk, dimana semakin rendah kadar air produk maka akan semakin lama daya simpan dari produk tersebut. Hasil analisis sifat amilografi dipilih dengan viskositas setback terendah, karena viskositas setback menentukan kemampuan retrogradasi pati dari tepung ganyong yang dihasilkan. Semakin tinggi nilai viskositas setback kecenderungan pati membentuk gel pada akhir pemasakan akan semakin tinggi, hal ini tidak diharapkan dalam pembuatan produk cookies, karena akan menyebabkan tekstur menjadi keras setelah produk dingin.

Hasil kadar amilosa dipilih dengan kadar amilosa yang sedang. Amilosa akan mempengaruhi tekstur dari cookies yang dihasilkan, dimana semakin tinggi kadar amilosa akan menyebabkan tekstur cookies yang dihasilkan menjadi padat. Hal ini disebabkan semakin tinggi kadar amilosa, kapasitas penyerapan air dan elastisitas semakin menurun sehingga kekerasan semakin meningkat (Ratnaningsih, 2010).

Tepung modifikasi terpilih diaplikasikan pada pembuatan cookies dan dilakukan pengujian organoleptik metode uji hedonik menggunakan 30 panelis belum terlatih, dimana kriteria penilaian berdasarkan tingkat kesukaan panelis terhadap karakteristik dari tekstur, warna dan rasa cookies tepung ganyong termodifikasi. Hasil analisis uji hedonik produk cookies dilihat pada Tabel 7 .

Tabel 7. Hasil Uji Hedonik Cookies 


\begin{tabular}{|c|c|}
\hline Atribut & $\begin{array}{c}\text { Rata-Rata Nilai } \\
\text { Keaukaan }\end{array}$ \\
\hline Wama & 4,03 \\
\hline Rasa & 4,40 \\
\hline Tekstur & 4,47 \\
\hline
\end{tabular}

Berdasarkan hasil organoleptik cookies tepung ganyong modifikasi pada Tabel 7 , didapatkan hasil ratarata nilai kesukaan panelis untuk atribut warna, tekstur dan rasa menunjukkan penilaian angka 4 (empat), yang artinya cookies tepung ganyong modifikasi ini disukai oleh panelis dalam hal rasa, warna dan tekstur.

Berdasarkan hasil penelitian, dapat diambil kesimpulan sebagai berikut :

1. Berdasarkan penelitian utama faktor (M) suhu pemanasan dan faktor $(\mathrm{N})$ waktu pemanasan serta faktor (MN) Interaksi antara suhu dan waktu pemanasan modifikasi Heat Moisture Treatment (HMT) berpengaruh terhadap kadar air, kadar amilosa, sifat amilografi dan kadar serat kasar.

2. Berdasarkan hasil organoleptik produk cookies tepung ganyong modifikasi Heat Moisture Treatment (HMT) terpilih disukai oleh panelis dalam hal rasa, warna dan tekstur.

\section{Daftar Pustaka}

1. Ahmad, L. 2009. Modifikasi fisik pati jagung dan aplikasinya untuk perbaikan kualitas mi jagung. Bogor : Tesis. Program Pascasarjana, IPB.

2. [AOAC] Association of Official Aalytical Chemist, (2005). Official Method of Analysis of The Association of Official Analytical of Chemist. Arlington: The Association of Official Analytical Chemist, Inc.

3. Badan Standardisasi Nasional.2008. SNI 6128-2008 Beras. Jakarta

4. Collado, L.S., L.B. Mabesa, C.G. Oates, and H. Corke. 2001. Bihon - type of noodles from heat-moisture treated sweet potato starch. Journal Food Science, 66: 604-609.

5. Dinas Pertanian Tanaman Pangan Kabupaten Ciamis. 2009. Pengembangan Agribisnis Ganyong. Ciamis : Dinas Pertanian Tanaman Pangan Kabupaten Ciamis.

6. Herawati, D. 2009. Modifikasi Pati Sagu dengan Teknik Heat Moisture Treatment (HMT) dan Aplikasinya dalam Memperbaiki Kualitas Bihun. Bogor : Tesis, Program Pascasarjana, IPB.

7. Hidayat, Nur.2010. Pati Ganyong Potensi Lokal yang Belum Termanfaatkan. Malang : Majalah Kulinologi.

8. Indrasti, N. S., Mangunwijaya, D., Nasution, Z., dan Chilmijati, N. 2001. The Characteristics of The Arrowroot Starch and Its Use As The Source Of Raw Material For Glucose Syrups. Bogor : Department of Agroindustrial Technology; Bogor Agricultural University.
9. Jyothi A, Sheriff J, \& Sajeev M. 2009. Physical and functional properties of arrowroot starch ex-trudates. Journal Food Science, 74(2), 97104.

10. Koswara. 2009. Teknologi Modifikasi Pati. Ebook Pangan.

11. Kusnandar, F. 2010. Kimia Pangan: Komponen Makro. Jakarta : PT. Dian Rakyat.

12. Muchtadi, R., dan Ayustaningwarno, F. 2010. Teknologi Proses Pengolahan Pangan. Bandung. Alfabeta. Pangesti, Y.D., Parnanto,

13. N.R., Ridwan, A. 2014. Kajian Sifat Fisikokimia Tepung Bengkuang (Pachyrhizus erosus) Dimodifikasi Secara Heat Moisture Treatment (HMT) dengan Variasi Suhu. Jurnal Teknosains Pangan Vol 3 No. 3 Juli 2014.

14. Pinasthi, Widi.2011. Pengaruh Modifikasi Heat Moisture Treatment (HMT) Dengan Radiasi Microwave Terhadap Karakteristik Fisikokimia Dan Fungsional Tapioka Dan Maizena. Bogor : Skripsi, Departemen Ilmu dan Teknologi Pangan, IPB.

15. Purwaningsih. 2013. Karakteristik Fisiko Kimia Tepung Ganyong Sebagai Pangan Alternatif Pengganti Beras. Prosiding Seminar Hasil Penelitian Tanaman Aneka Kacang dan Umbi.

16. Puung, Victoria F. 2012. Karakterisasi Sifat FisikoKimia Pati Ubi Jalar Ungu (Ipomoea Batatas L.) Termodifikasi Perendaman dan Heat Moisture Treatment (HMT). Fakultas Teknologi Pertanian. Universitas Brawijaya.

17. Ratnaningsih, Nani. 2010. Perbaikan Mutu dan Diversifikasi Produk Olahan Umbi Ganyong Dalam Rangka Meningkatkan Ketahanan Pangan. Yogyakarta : UNY.

18. Septian, 2010. Peran Kelembagaan Kelompok Tani Terhadap Produksi Dan Pendapatan Petani Ganyong Di Desa Sindanglaya Kecamatan Sukamantri Kabupaten Ciamis Jawa Barat. Bogor : Skripsi, Fakultas Ekonomi dan Manajemen, IPB.

19. Siwi, Kharinda S. 2012. Studi Perubahan Sifat Fisik Kimia Tepung Ubi Jalar Putih (Ipoema Batatas) Sebagai Efek Modifikasi Menggunakan Metode Heat Moisture Treatment. . Universitas Brawijaya.

20. Soekarto, T. Soewarno. 1985. Penilaian Organoleptik untuk Industri Pangan dan Hasil Pertanian. Jakarta : Bhratara Karya Aksara.

21. Sudarmadji, (2003). Analisa Bahan Makanan dan Pertanian. Yogyakarta : Liberty

22. Sumarlin. 2011. Karakterisasi Pati Biji Durian (Durio Zibethinus Murr,) Dengan Heat Moisture Treatment (HMT). Teknologi Hasil Pertanian, Fakultas Pertanian. Universitas Riau. 
23. Stute, R. 1992. Hydrothermal Modifications of Starches. The Difference between Annealing and Heat Moisture Treatment. Starch, 44: 205214.

24. Syamsir, E. Hariyadi, P.,Fardiaz, D. Andarwulan, N., Kusnandar, F. 2012. Pengaruh Proses Heat Moisture Trearment (HMT) Terhadap Karakteristik Fisikokimia Pati. Bogor : Jurnal Teknologi Pangan. IPB.

25. Takahashi ., Ohisa., Mori and Kobayashi. 2005. Heat Treatment Of Milled Rice and Properties Of The Flour.Cereal Chemistry. 82(2):228-232.

26. Utami, 2010. Modifikasi Pati Ganyong Dengan Teknik Heat Moisture Treatment (HMT) Dan Aplikasinya Dalam Pembuatan Sohun Dengan Penambahan Hidrokoloid. Bogor. IPB

27. Winarno, F.G. 2002. Kimia Pangan dan Gizi. Jakarta : PT Gramedia Pustaka Utama.

28. Zavareze, E.D.R dan A.R.G. Dias. 2010. Impact of heatmoisture treatment and annealing in starches: Areview. Carbohydrate Polymer 83: 317-328. 